\title{
NATURAL MATERIALITY: WATER AS AN ACTIVE ELEMENT OF THE GARDENS BY DENIS MCCLAIR AT VOLHYNIA
}

\author{
Petro Rychkov ${ }^{1}$, Nataliya Lushnikova ${ }^{2}$ \\ ${ }^{1}$ Department of Historic Building Preservation, Faculty of Civil Engineering \\ and Architecture, Lublin University of Technology
}

${ }^{2} \mathrm{PhD}$ (Eng.), Associate Professor, Department of Architecture and Environmental Design, Institute of Civil Engineering and Architecture, National University of Water and Environmental Engineering, Rivne, Ukraine

\begin{abstract}
The paper gives coverage to peculiarities of water elements application in landscape compositions created in $19^{\text {th }}$ century by gardener of Dionizy Mikler (Denis McClair) at Volhynia. Being an ambassador of English landscape garden style in this region D. Mikler seamlessly integrated picturesque natural and artificial water components in the garden structure. There are considered the role and ways of interaction of water elements with the landscape compositions by giving examples of Polish landowner's residences in Gorodok, Mizoch, Mlyniv and Shpaniv.
\end{abstract}

Keywords: Dionizy Mikler (Denis McClair), water, English landscape garden, landscape composition, Volhynia.

This paper develops the ideas on water as natural element within the structure of landscape gardens by Dionizy Mikler in Volhynia, now North-West part of Ukraine, presented in conference paper [1]. It is widely accepted that water is an essential 'material' in the landscape architecture, equally with landforms and vegetation. Artists often compare water with a rich palette, which can give unique results in the hands of a skilled master of landscape.

To provide picturesque garden or park there are many ways of application of water aesthetics: reflection of the surrounding landscape in the mirror-like surface to form a certain visual balance; variety of views depending on weather conditions (waves, ripples, drops' falling, etc.). Acoustic properties of water are also of great importance for aesthetic impression: purling of streams, noise of full-flowing rivers, different sounds at the water fall on various surfaces. British landscape architect and garden designer Sylvia Crowe wrote that moods to which water serves are as varied as human temperament. Water can be careless, or active, or thoughtless... [2]. In the work 'The landscape of reservoirs' she summarized: "The essential element of reservoirs, the water, is an asset to any landscape and the landscape architect's task is to see that it lies happily and unfussed within the landform with that look of inevitability which is the hallmark of good design" [3]. Water is full of deep symbolism. In Eastern philosophy, a playful stream symbolizes life line, and pond, at which it flows, creates an idyllic landscape and carries the meaning of "life generator", "park eye" [4].

Water surfaces are not only objects of contemplation; they create a certain distance, a kind of perception front for garden landscapes. Water resources along with landforms are usually decisive in formation the planning structure of the garden. Ponds can serve as a passive background for the garden compositions, but more often they actively interact with both landforms and vegetation, and with buildings and structures. Spatial relationship between garden and pond is ambiguous: the water reservoirs may be located in the garden, or vice versa - garden is located near the water reservoir - on the banks of rivers, large water areas. In the last case, a spatial solution of the garden obeys to water reservoir and is created considering orientation to the pond. Local conditions give hints about possibilities of creation of various water facilities.

The interaction of the landform with water may be intensified by vegetation bank line, construction of dams and artificial islands, building bridges [5]. Bank strip, as well as more distant areas of the garden, which includes the panorama of the reservoir in the view field, is 
important area for the formation the picture of landscape. Paths' route lies through the viewpoints at which these pictures are seen.

Upon exploring the history of landscape architecture, there is no doubt that the capacities of water objects have been well known in the past. It is quite natural that water was one of the most important elements of landscape gardens, the most common in the 18 century. Rationalistic perception of the world, typical of the Age of the Enlightenment, its appeals to nature and to human being as part of nature, inspired the poets and writers to create idealistic pictures of the gardens of Eden. And landscape gardening art trends to move off the formalism of regular compositions, as symbols of the dominant position of human in nature, and to convers landscape outlook, the main feature of which was the reproduction and transmission of natural beauty of a landscape, or its slight adjustment. The idea of creation of landscape gardens was born and became prevalent in England. Natural conditions of the country with a mild climate and low hills, spacious meadows, diffused lighting, plenty of rivers have been aided to it.

Nicholas Pevsner aptly remarked that landscape garden grew out of the ideas philosophers and writers - not architects or gardeners, and it was a product of cultural climate change resulting in liberal political climate [6]. Although the beauty of nature was praised constantly by the artists, and the poets in their writings traced the images of paradise gardens [7], there only in the 1710's after active criticism of formal jardin à la française in works by Joseph Addison, [8], Alexander Pope [9] and other authors the age the landscape style rule started, or according to Dmitriy Likhachev, ,triumphant advance of the natural landscape on chopped off and clipped vegetation regular garden» [10].

Usually the characteristics of landscape parks experienced changes direction according to the aesthetic preferences of his time, landscape and climatic conditions. However, some rules remained unchanged. In particular, it considers water element as the most important one in the landscape garden. As ,it (the water - N.L.) attracts us and delights, the - life in it” - as Jacques Delille wrote in his poem „The Gardens" - a praised ode to landscaped gardens and actually poetic guide to their creation [11]:

And ye streams, rivers, lakes, and fountains, thence

New life, new freshness, new delight dispense.

How bright your blue translucent waves appear!

From far entice us, and amuse us near.

It should be noted that the most prominent representative of the latest generation of artists and theorists of the English landscape park was Humphry Repton, who believed that the mere imitation of nature or the rules of painting are just a part of garden art. Therefore, influencing on nature, creating artificial water reservoirs, forming groups of trees by cutting and planting, great effect can be reached [12]. Dionizy Mikler is considered as a follower of such creative style [13]. In Ireland Mikler is known although for his co-operation with Thomas Legget, who is appraising commonly as 'celebrated landscape gardener' [14], active in 1770's - 1810's [15].

New tendencies of garden fashion from the West have penetrated into the territory of the continental Europe and in particular to Volhynia. For creating landscape gardens near magnate residences in Poland, and later in Russia, best European architects and gardeners were enlisted. Among them was also an Irishman by birth, gardener and botanist by education Dionizy Mikler, whose professional activity was indivisibly associated with Volhynia and Podillia.

It should be mentioned that his long way to this region was started due to invitation of Princess Izabela Czartoryska, who was looking for the gardener for own landscape park in London. Her inspiration with landscape gardens was implemented in the well-known guide work on gardens design [16].

Several studies of his work describe Dionizy Mikler as the creator of a large number of parks in the territory of Volhynia and Podillia. Selected memoirs of his contemporaries and customers, such as the famous writer, historian Alexander Pszezdecki [17], indicate a large 
number of gardens created by Mikler. Josef Dunin-Karwicki also mentioned and described some of Volhynian gardens [18]. In modern times, the most reputable research is monumental work on palace and garden ensembles, was made by Roman Aftanazy [19]. The detailed research of several Volhynian gardens was conducted formerly by Krystyna Żelechowska and Gerard Ciołek [20].

At present the creative work by Dionizy Mikler attracts the attention mostly Ukrainian [21-23] and Polish researchers [24-26], but also Irish authors inspired by an exotic career of their countryman $[27,28]$.

According to the accumulated data, only in the Volhynia, there are about 40 gardens, to create which most likely Dionizy Mikler has put his hands (Fig. 1). As any other landscape architect and gardener, laying the garden or transforming existing one, Mikler had certainly taken into consideration the local natural factors such as relief and availability of water, and location of existing buildings and structures. Mikler was often obliged to process regular gardens, close to existing palace ensembles, adapting to the existing topography and hydrological situation, rarely he designed new garden, created simultaneously with palace (Kryvyn, Mizoch, Shpaniv) or outside the palace ensemble like his first project at Volhynia - garden named "Palestine" near Dubno.

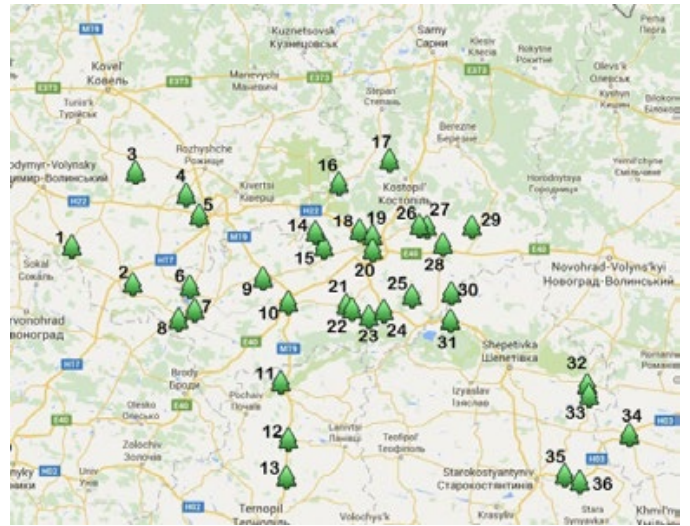

Fig 1. Spatial localization of the gardens by Dionizy Mikler on the territory of historical Volhynia, created by N. Lushnikova, based on accumulated data [17-19]; Google Maps App: 1 - Staryi (Old) Poryck; 2 -

Kholoniv; 3 - Voronchyn; 4 - Ivanchytsi; 5 - Zaborol;

6 - Boremel; 7 - Verben; 8 - Berestechko; 9 - Mlyniv; 10 - Dubno; 11 - Kremenets; 12 - Vyshnivets;

13 - Kolodne; 14 - Radukhivka; 15 - Humennyki;

16 - Derazhne; 17 - Pidluzhne; 18 - Horodok;

19 - Shpaniv; 20 - Rivne; 21 - Stublo; 22 - Mizoch;

23 - Derman; 24 - Verkhiv; 25 - Ozhenyn; 26 -Shubkiv;

27 - Tuchyn; 28 -Chudnytsa; 29 - Nevyrkiv; 30 -

Kurash; 31 - Kryvyn; 32 - Polonne; 33 - Novoselitsa; 34 -Lubar; 35 - Samchyki; 36 - Ladyhy

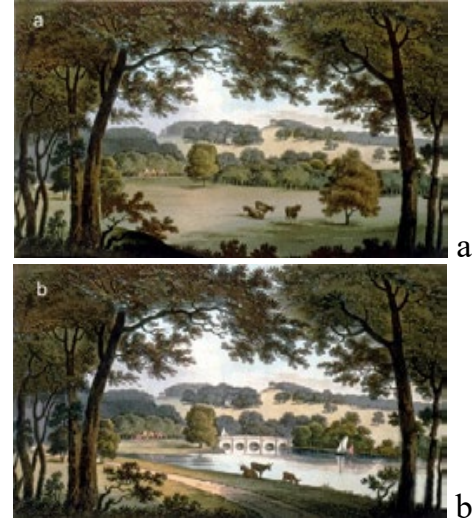

Fig. 2. a) Water at Wentworth, Yorkshire. Site at Wentworth, South Yorkshire before proposed landscaping // Observations on the theory and practice of landscape gardening: including some remarks on Grecian and Gothic architecture, collected from various manuscripts, in the possession of the different noblemen and gentlemen, for whose use they were originally written; the whole tending to establish fixed principles in the respective arts by H. Repton. London, Printed by T. Bensley, Solt Court, for J. Taylor, at the Architectural Library, High Holborn.1805. Avaiable at: https://archive. org/stream/observationsonth00rept\#page/40/ mode/2up. Public domain; b) Water at Wentworth, Yorkshire. Site at Wentworth, South Yorkshire after proposed landscaping. Ibid. Avaiable at: https:// archive.org/stream/observationsonth00rept\#page/ n79/mode/2up. Public domain. 
We should not but mention the similarity landscapes of his homeland and Volhynia. Hilly plains dominated the center of the Emerald Isle where Dionizy Mikler was born near Athlone and spent his early years, are rich with rivers, lakes and peat bogs. At the same time Volhynian landscapes are notable for saturation with water sources, scenic bank lines. In this way, A. Pszezdecki writes about "a variety of palaces and parks ... over rivers and lakes in Volhynia" [29]. Since ancient times settlements were formed near water sources or waterways, and along with the estates, traditionally pounds were held. Therefore, both natural and artificial reservoirs were an integral element in the composition of the palace and garden ensembles in the second half of the $18^{\text {th }}-19^{\text {th }}$ centuries [30]. Therefore, we take the liberty to state that long and fruitful professional life of Mikler at Volhynia is indebted (among other) to similarities of landscapes and natural conditions: as it can be said, that here he found part of his Motherland.

Referring to the landscape heritage of Dionizy Mikler, it seems absolutely appropriate and necessary to point out to what extent and in what way the water was present in his many implementations, particularly in Volhynia.

Being a gardener and botanist, Dionizy Mikler, unfortunately for us, descendants and scholars of his work, did not leave any handwritten or pictorial evidence of his own works, as, for instance, Humphry Repton did. With his real works only, we can imagine how water changes the view of the garden (Fig. 2a and b).

At present, most of the garden compositions are lost, the palaces were destroyed or rebuilt, and water systems are distorted or destroyed as well as separate landforms. However, existing landmarks such as forests, ruins of palace complexes, traces of river beds, testimonies of local residents, along with extant drawings, lithographs, plans of those times give us some idea about general appearance of landscape compositions and their relationship to landforms and water.

To our opinion, there are several major aspects of integration of water elements in gardens (often, however, the palace and gardens) compositions.

The first and most important task was the need in organic combination of laid out garden with natural water formations (rivers, streams, lakes, springs, etc.). Of course, freedom of choice of these sites often had serious limitations because of the presence of existing buildings. Therefore, in some cases, dislocation had to be changed.

The second aspect dealt with the need to create artificial water bodies - lakes, canals, dams, cascades, fountains, pools, ponds, etc. These water bodies allowed to adjust the hydrological situation, adapting it to the overall composition of a garden or even gave an opportunity to change fundamentally the situation in a particular area, raising significantly water level. It is difficult to find an example in Volhynian gardens, where such artificial hydrotechnical facilities were absent.

The third aspect was in adapting water surfaces to the functional filling new garden formations. The presence of water considerably enriched these opportunities through the construction of scenic walking tracks along the banks, artificial canals for boating, a number of different small bridges on walking routes, baths, berth, places for fishing, and so on.

Fourth important task for the master was the use of water for aesthetic purposes. At that, of course, overall composition of the palace and garden ensemble was taken into account. Between residential buildings and water attractive landscape vistas created, which provided a visual connection of open water surfaces with individual recreational elements of architectural building infrastructure - galleries, verandas, balconies, attic floors, loggias, pergolas, at any period of the year.

Finally, a special factor of water aesthetization and its integration into garden composition was careful selection of vegetation served, as if it should emphasize the character of the terrain along with water topography. At bank line more hydrophilous trees species and brushes (willows, osiers, aspens) were located and higher at the terrain - a monumental and many years standing vegetation (oaks, lindens, ashes, chestnuts, maples, etc.). 
According to the fixed layout planning structures of water elements in cities [30], including artificial ponds in general and in [31] palace and garden ensembles in particular [32], there can be defined basic ways of interaction between water elements and garden compositions, including those created by D. Mikler (Fig. 3).
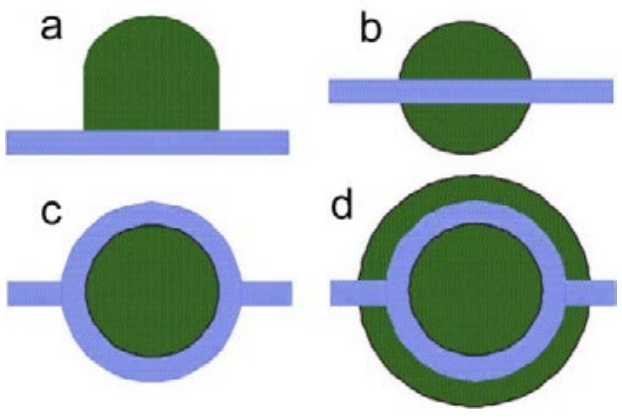

Fig. 3. Basic principles of land surveying of garden compositions with water elements of landscape (schemes by N. Lushnikova): a) one-faced; b) double-faced; c) - island; d) combined.

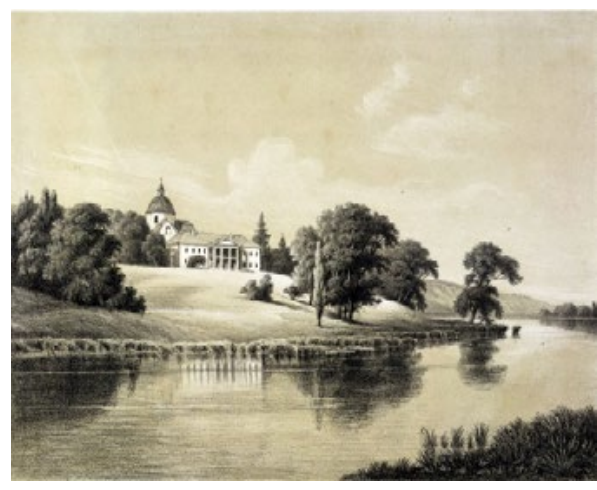

Fig. 4. Gorodok. General view of the palace and garden. Lithograph by H. Peyer. 1850-s.

Mostly water elements of the landscape served as boundaries of the territory of garden compositions or palace and garden ensembles. At varying degrees of contact such one-faced surveying of landscape composition with water elements - rivers, their tributaries and artificial ponds created by dams can be seen in the palace and garden ensembles in Boremel and Verben, Kholoniv on the river of Styr, Old Kryvyn on the river of Horin and Mizoch on the river of Stubla, Lubar, Ladyhy, Samchyki on the river of Sluch, Mlyniv on the river Ikva, Novoselytsa and Polonne on the river Khomora and others (Fig. 3a). Double-faced land surveying of the garden with water elements [Fig. 3b] can be found in Berestechko [33] and Shpaniv, island - in Horodok [34[, Porytsk [35] (Fig. 3c).

There were also combined surveying, such as the combination of an island with palace and one-faced garden (Fig. 3d). Palace and garden complex in Rivne can be considered as the most notable of these examples. It was formed in the second half of $18^{\text {th }}$ century, also obviously not without Mikler participation in the next time. The active role of water in this ensemble was a distinctive feature. The bulk of the water surface was created simply raising its level by placing dams on the river of Ustia in the northwest part of town. As the result became quite lengthy pond with several islands formed - almost equal by its area to old town. However, at the plan, performed by J.J. Bourguignon, were fixed artificial canals and small lakes [36].

Combined survey was also characteristic feature of the famous recreational garden Palestine in Dubno, located far from the rebuilt castle. Part of the garden laid out at the swamps above the Ikva [37] on an artificial island, the creation of which Mikler led [38]. The latest example is only known autonomous formation landscape garden formation in the biography of D. Mikler created on a remote western suburbs along the high left coast of Ikva. The choice of the site was, apparently, not accidental. It was not only because of the flooding; due to the dam constructed downstream near the castle, in the summer days, there has been opened a huge mirror Dubno pond. In quiet days, the hills of Kremenets mountain ridge quaintly reflected in it.

The first artificial water element - channels and ditches that have protective functions for defenses, in the second half of $18^{\text {th }}$ century were replaced by artificial ponds, built on small 
rivers and on natural lowlands of the simplest water flow regulating structures - dikes. In this way, individual ponds (Mizoch) or cascades of them (Mlyniv) were created. During the planning of the palace and garden ensembles, which territory was not watered enough, artificial water basins (channels, ponds) and various artificial devices associated with the use of aesthetic and acoustic properties of water: fountains, cascades of ponds, have been created [39]. Artificial ponds enriched gardens composition in Kryvyn, Shpaniv [40], Humennyki [41].

In the second half of the $18^{\text {th }}$ century by lost their defensive functions, the old castles mostly were rebuilt into classical palaces. On the slopes of formerly treeless hills gardens and parks were laid out, gradually descending to the water (Verhiv, Vyshnevets, Pidluzhne a.o.), forming a water distant prospects. Here, the water has played a passive role being a fragment of the background of the whole composition. Twisting river banks often create a number of beautiful perspectives, opening views of the opposite bank as it can be seen in the palace and garden ensemble in Tuchyn [42].

Specific solutions as to the integration of water elements in the palaces and garden ensembles and their current state can be illustrated by comparative examples of former residential estates in Gorodok, Mizoch, Mlyniv and Shpaniv.

Gorodok. Esterházy palace and St. Nicholas Church were located on the large island formed by the splats of the river Ustia (Fig. 4). The island presented a plateau, which slopes on the east are rather steep, but to the west and south it slopes gently to the water [43]. On the east edge of the upland the palace and the church were located. Garden designed by Mikler before 1820 was also located there [44]. The garden had roads to ride, many beautiful old trees and wooden bridge on the piles led to the palace. The principal front of the palace was oriented on the pond and lawn, with a long flowerbed [45]. Part of the coastline facing the city was decorated with trellis trees (in the south-east of the island), which gradually turned into separate groups and single poplar trees on the southern coastline (Fig. 4). The same trellis was planted on the opposite bank. Thus water, park and hardly engaged vegetation were the main factors barrier of the island with views on the free water in the south and the west derection. In front of the portico of the palace flowerbed was placed, in the lower part of which line of trees was located, to create shade for walking paths (Fig. 5.a). In places where views on the distant water were open to the south and east, the mass of chestnuts, and arrows of poplars and groups of spruces clearly accentuated the forefront. The old willows, that hung over the water, emphasized the mood of the panorama. West bank of the island was planted by poplars that covered the opposite banks of the village side [46].

Walking path along the bank allowed admiring mirror-like surface in close (Fig. 5a). At present, the garden is partly lost. The palace and the church survived and are part of the St. Nicholas Gorodok Convent (Fig. 5b, 6). The way of communication with the opposite bank remained unchanged. 


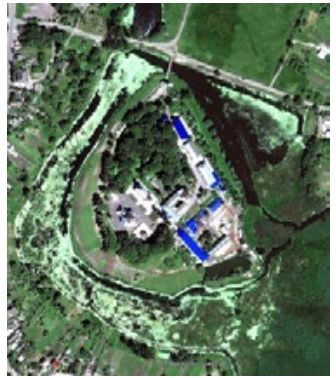

a

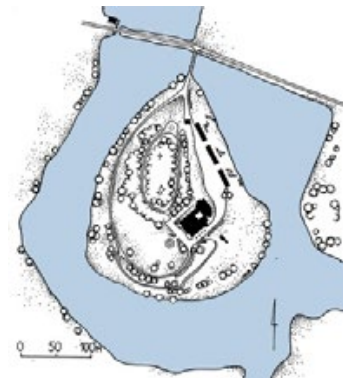

b

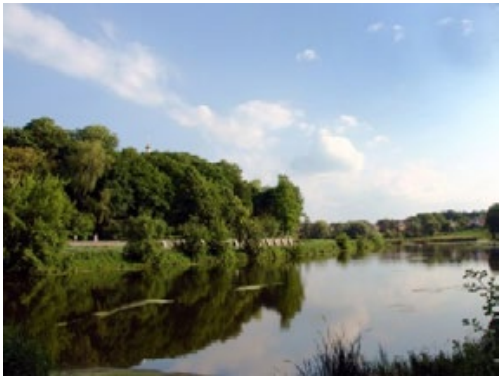

Fig. 6. Gorodok. Territory of palace and garden ensemble. Present state. Photo by P. Rychkov. June 2012. and G. Ciołek, redrawn by P. Rychkov; b) current state of former palace and garden location (at present Female Orthodox Monastery of St. Nicholas), Google Earth image.

Mizoch. Palace and garden ensemble of Prince Y. Dunin-Karvycki was located in the western part of Mizoch. Palace and garden complex were built in the 1790's. [47]. There were a dozen hectares of landscape garden around the palace, typical for those laid out by Mikler [48]. Garden covered mainly the south-western part of the residence, in front of the principal front of the neoclassical palace; it descended down to the artificial pond created by Mikler on the overflow of the river of Stubla 9 (Fig. 7a). In the garden, terraces were placed, balustrades, orangery, swimming pools, and a large number of old trees were located [49]. Mikler rearranged existing coniferous and deciduous trees, visually connecting them with balustrades, terraces, towers as well as with orangery. Trees on the bank line were mainly planted in groups. Small artificial island gladden the eye (Fig. 7a).

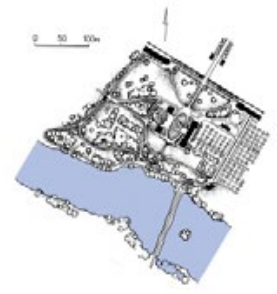

a

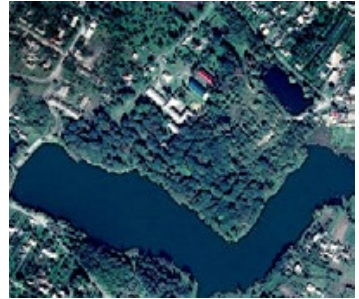

b

Fig. 7. Mizoch: a) garden plan in 1938 by K. Żelechowska and G. Ciołek; redrawn by P. Rychkov; b) current state of former palace and garden location, Google Earth image.

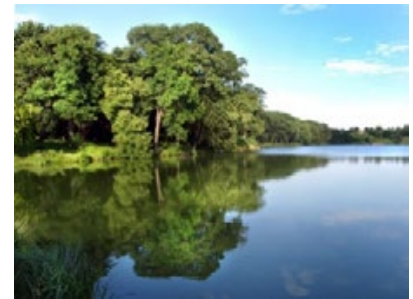

Fig. 8. Mizoch. Territory of palace and garden ensemble. Present state.

Photo by P.Rychkov. June 2012.

Interesting is the fact that the principal front of the palace was not oriented on the water but on the park: main axis of the building was parallel to the bank line. As the large palace, main façade of which had to be oriented to the lake, was not built, the composition lacked completeness (Fig. 7a). There was a picturesque view of the lake and the opposite bank, where menagerie was located. It was connected to palace and garden ensemble with dam.

Now the garden looks like overgrown forest with ruins of a single building - orangery overlooking the abrupt bank of the pond (Fig. 8). The dam was flooded due to raising the water level by about $3 \mathrm{~m}$ at the construction of a new dam (Fig. 7a, 7b).

Mlyniv. Residence of family counts Chodkiewicz was located on the rather high left bank of the Ikva River (Fig. 9, 10, 11a). The ensemble of 15 hectares could be divided into two parts: the southern one directly connected with the palace and other buildings, and the second 
one - located on both sides of the channel - the horns of the river, on rather steep slopes that create authonomous romantic composition closely related to the manor territory [50]. Water accents formed an small artificial island with separate trees and walking paths in the western part of the complex and artificial bank with espalier planted on it in the northeastern part formed water accents (Fig. 11a).

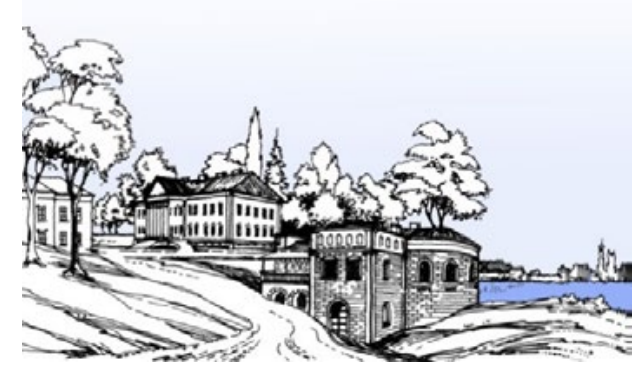

Fig. 9. Palace and garden ensemble in Mlyniv: axis of the main building was oriented on the pond. Redrawn by P. Rychkov according to the sketch by Napoleon Orda.

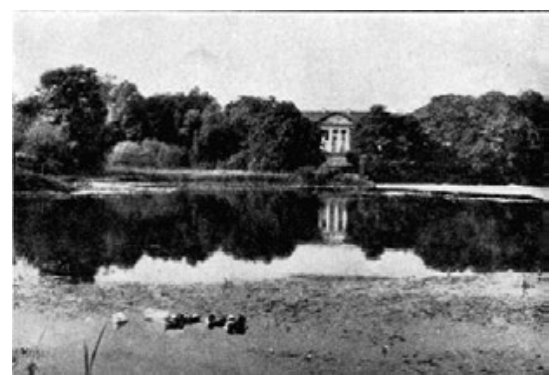

Fig.10. Mlyniv. Northern façade of the palace from the riverside of Ikva. Photo by

K. Żelechowska and G. Ciołek, 1938.

Axis of the wide entrance in the form of grass lawn was narrowed by trees frame and continued on the opposite side of the palace by the view on the town and Ikva. On both sides of the channel were planted picturesque groups of trees and bushes, creating variety of water reflections [51]. In fact, the channel was a cascade of three ponds created through the construction of dams. Water facilities and garden preserved up to this day (Fig. 11b, 12).

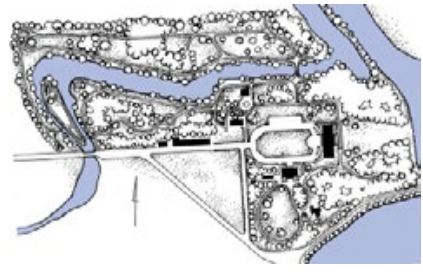

$\mathrm{a}$

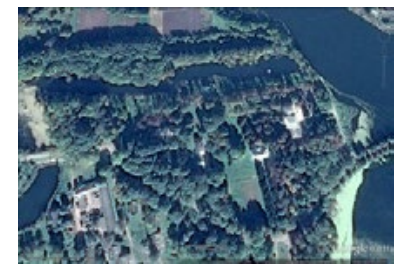

$\mathrm{b}$

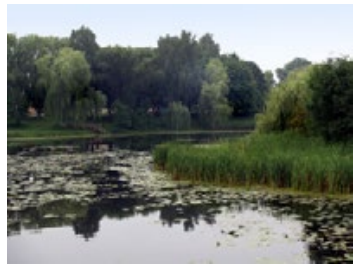

Fig. 12. Mlyniv. Fragment of the side channel. Current state. Photo by P. Rychkov. June 2006.

Shpaniv. Actually garden, was founded by Mikler, but perhaps redesigned with the participation of Alexandra Radziwill, It had an area of about 20 hectares (Fig. 13). It occupied mainly high eastern bank of the pond, crossed with many paths (Fig. 14a). The lower opposite bank gradually passed into sprawling meadows, swamps and flood water [52]. The garden was laid out the only a narrow strip of eastern bank [53]. North bank of the pond was formed as a plateau, crossed by channel from the east. Over the channel stone bridge spanned, being a part of entry alley. From the south, a view of the part of the garden and pond among the groups of spruces and larches was opening. Paths were around the pond. On the east bank cut down a wall of trees and bushes open views of the palace and pond. 


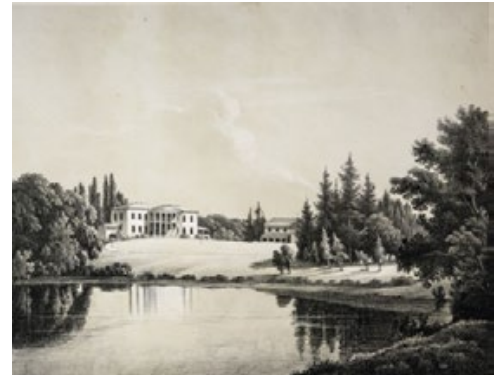

Fig. 13. Shpaniv. General view of the palace and garden. Lithograph by H. Peyer.

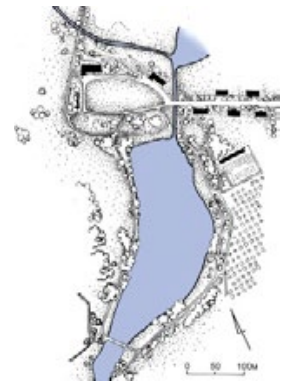

a

Fig. 14. Shpaniv: a) garden plan in 1938 by K. Żelechowska and G. Ciołek redrawn by P. Rychkov; b) current state of former palace and garden location, Google Earth image.

It should be noted great inspiration of the Radziwills by the natural beauty of the garden, with lowlands, washed by streams, with wilderness and fields. Princess Helena Radziwill summarized that ,art never be compared with nature» [54] after one of her visits to Shpaniv. Today, only a few elderly limes and ashes, which comprises about 200 years remind about the garden. Water elements degraded and turned into meadows and marshes (Fig. 14b, 15).

Thus, within the structure of landscape gardens in Volhynia, in particular those created by Dionizy Mikler, water elements assigned to play one of the main roles. As a gardener and botanist, he had typical romantic vision of nature, with minimal interference with it. As a representative of the authentic English Landscape garden style, not distorted by regional transformations he has brought his vision of the garden in the context of existing natural and artificial factors, creating his own style, discerned at many gardens in the territory of Volhynia. As rightly observed A. Pszezdecki, biography of Dionizy Mikler - is at the same time a history of the landscape garden design Volhynia and Podillia [55].

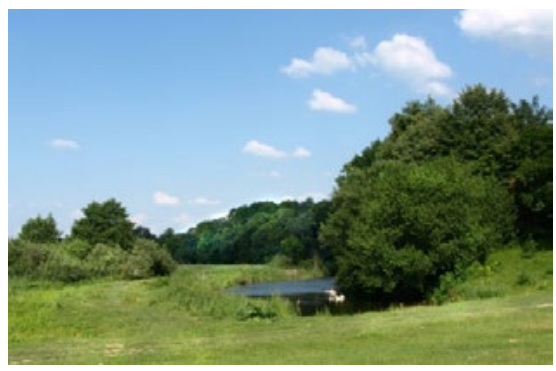

Fig. 15. Shpaniv. General view of the former palace and garden ensemble from the west. Present state. Photo by P. Rychkov. June 2012.

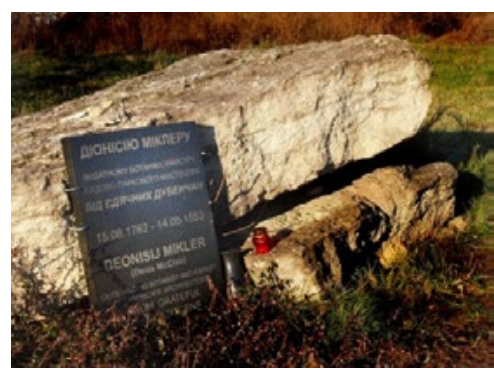

Fig. 16. Memorial stone for Dionizy Mikler, placed at the place of old Polish cemetery, where he was buried. Photo by P. Rychkov, Dec. 2015.

Unfortunately, deprivation of most of garden-compositions and limited information about the conditions and circumstances of their creation do not allow us to be confident in authenticity of gardens, peculiarities their original structure and of the role of water elements in most of them. However, the characteristic features of D. Mikler individual style in the context of its interaction with the creations of water resources is still possible to outline. Despite of significant differences between considered garden compositions, they had inherent and common features, including artificial ponds, integration artificial islands with plantings into the composition, orientation of the principal fronts of the main buildings to the water, the disclosure of specific perspectives on water landscape elements from the bridges, with bank lines in „windows" 
among groups of trees from the paths leading to them. It should be noted as cooperation with the owners of residences that often became co-authors s and followers of Dionizy Mikler style. Without any doubt, his work had a significant impact on the architecture of Right-Bank Ukraine.

It is a symbolic that he ended his days in the place where he started an amazing career of a gardener in Volhynia - namely in Dubno and was buried there at the Polish cemetery near the chapel. Unfortunately the cemetery exists no more and the exact place of the burial is lost. However, the memory of the illustrious masters of landscape art continues to live on in the form of a memorial plate installed in honor of $250^{\text {th }}$ anniversary of his birth (Fig.16).

\section{BIBLIOGRAPHY}

1. Лушнікова Н.В., Ричков П.А., 2012. Вода як природний «матеріал» в структурі ландшафтних парків Діонісія Міклера на Волині.// Парки Діонісія Міклера: Матеріали міжнародної науково-практичної конференції присвяченої 250-ї річниці $з$ дня народження видатного ландшафтного дизайнера, а також формуванню та розвитку садово-паркового мистецтва на землях Східної Європи. - Збараж-Вишневець-Кременець, - С. 65-76.

2. Crowe S., 1994. Garden Design, Published by Sothebys Pubns.

3. Crowe S., 2001. The landscape of reservoirs. London: Association of River Authorities, 1969. Quoted from: Taylor K. Sylvia Crowe: Innovator and Exemplar, Landscape Review, 7(1) P. 43-46.

4. Wong M. A Synopsis of the Culture of Chinese Gardens, Dunedin Chinese Gardens Trust (February 2009) 14 p. Available at: http://wenku.baidu.com/view/0f78f800a6c30c2259019e61.html

5. Alexander R., 2009. The Essential Garden Design Workbook. 2nd ed. Portland/London, Tmbe Press, -302 p.

6. Pevsner N., 1994. The Genesis of the Picturesque.

7. Milton J. Paradise Lost: (1674 version)/ Available at: http://www.gutenberg.org/cache/epub/20/pg20-images.html

8. "Pleasures of the Imagination" by Joseph Addison, Reading For Philosophical Inquiry: Article Series, Available at: http://philosophy.lander.edu/intro/articles/addisonart-a.pdf.

9. Pope A. Epistle IV, to Richard Boyle, 1904. Earl of Burlington in Moral Essays. New York: Macmillan, 260 p.

10. Лихачев Д.С., 1987. Жак Делиль - учитель садоводства.// В кн.: Делиль Ж. Сады. - Л., - С. 211.

11. The Gardens. A poem. Translated from The French of the Abbe De Lille by Mrs. Montolieu. The 2nd edition. London, Printed by T.Bensley, Bolt Court, 1805. Available from: http://books.google.com/.

12. Observations on the theory and practice of landscape gardening: including some remarks on Grecian and Gothic architecture, collected from various manuscripts, in the possession of the different noblemen and gentlemen, for whose use they were originally written; the whole tending to establish fixed principles in the respective arts by H. Repton. London, Printed by T.Bensley, Solt Court, for J.Taylor, at the Architectural Library, High Holborn.1805. Avaiable at: https://archive.org/stream/observationsonth00rept\#page/40/mode/2up.

13. Родічкін І., Родічкіна О., 2006. Старовинні маєтки України. - К.: Мистецтво, - С. 90-99.

14. A Statistical and Agricultural Survey of the County of Galway: with observations on the means of improvement; drawn up for the consideration, and by the direction of Royal Dublin Society by Hely Dutton. Dublin: Printed at the University Press, by R. Graisberry, Printer to the Royal Dublin Society, 1824. Available at: http://www.archive.org/ stream/astatisticaland00duttgoog\#page/n6/mode/2up.

15. Legget T. Irish Architectural Archive, Dictionary of Irish Architects (1720-1740). Available at: http://www.dia.ie/ architects/view/3153/LEGGETT-THOMAS.

16. Myśli różne o sposobie zakładania ogrodów. Przez Izabela Czartoryska (księżna) we Wrocławiu Drukiem Wlihelma Bogumiła Korna. 1805. Pryedruk, Wydawnictwo Artystycyne i Filmowe, Warsyawa, 1979.- 122 s.

17. Przezdecki A., 1841 Ogrody Miklera // W ks.: Podole, Wołyń, Ukraina: obrazy miejsc i czasów. T. 2. - Wilno, s. 126-141.

18. Dunin-Karwicki J., 1893. Przejażdżki po Wolyniu : obrazki z przeszłości i teraźniejszości. Lwów : nakl. autora, (Lwów: W. Łoziński). 91 s./ Dostęp: http://polona.pl/item/1246765/51/.

19. Aftanazy R., 1988. Materiały do dziejów rezydencji. - T.5a. Dawne województwo Wołyńskie. - Warszawa, Passim.

20. Михайлишин О.Л. Одна з втрачених назавжди? Резиденція і парк в Івниці на Житомирщині.// Парки Діонісія Міклера: Матеріали міжнародної науково-практичної конференції присвяченої 250-ї річниці з дня народження видатного ландшафтного дизайнера, а також формуванню та розвитку садово-паркового мистецтва на землях Східної Європи. - Збараж-Вишневець-Кременець, 2012. - С. 118-126.

21. Żelechowska K., Ciołek G., 1939. Ze studiów nad załoźeniami ogrodowymi Wołynia. Sprawozdanie z badań z roku 1938. - Warszawa, s.22. 
22. Родичкіна О., Родичкін І. «Майстер садово-паркового мистецтва: життя і творчість Діонісія Міклера в Україні», Архітектура України, К., 1992, № 3, С. 33-39.

23. Мельник В.І. Діонісій Міклер (до 230-річчя з дня народження) / В.І.Мельник // Український ботанічний журнал. - 1993. - Т.50. № 1. - С.177-178.

24. Brzezińska-Marjanowska W., 2014. Parki i ogrody projektowane przez Dionizego Miklera // Klasycystyczne założenia pałacowo-ogrodowe na Wołyniu 1780-1831. Polski Instytut Studiów nad Sztuką Świata, Wydawnictwo Tako, Warszawa-Toruń s. 251-264.

25. Kibort P., 2012. Ogrody w majątkach Mniszków w końcu XVIII i na początku XIX wieku: Dęblin, Tatary, Gródek Podolski, Wiśniowiec Nowy// Парки Діонісія Міклера: Матеріали міжнародної науково-практичної конференції присвяченої 250-ї річниці $з$ дня народження видатного ландшафтного дизайнера, а також формуванню та розвитку садово-паркового мистецтва на землях Східної Свропи. - Збараж-Вишневець-Кременець, C. $95-107$.

26. Piórecki J., Dubiel E., 2009. Volhynian Polesia-main source of the Yellow Azalea (Rhododendron luteum Sweet) in European gardens and parks. Rocznik Polskiego Towarzystwa Dendrologicznego. Vol. 57 29-32.

27. Bowe P., 2002. Art and Nature. The Polish and Ukrainian Gardens of Denis McClair (1762- 1853): chronicles the exotic career of an Irish landscape gardener and emigre in the $19^{\text {th }}$ century// Irish Arts Review Yearbook, p. 176-184.

28. Nelson C., 2013. Garden history: Dionizy Mikler// The Irish Gardener, p.46-49.

29. Przezdecki A. Op.cit. - S. 126.

30. Михайлишин О.Л. Палацово-паркові ансамблі Волині 2-ї половини XVIII-XIX століть. - К., 2000. - 234 с.

31. Рычков П.А. Градостроительное искусство Зап. Украины XV-XIX вв. - Дисс. д-ра архитектуры. - Т.2. - М., 1993. - C.8.

32. Носар І.В. Штучні водойми в планувальній структурі історичних міст Волині // Містобудування та терит. планування. - Вип. 16. - К., 2003. - С. 130-145.

33. Михайлишин О.Л. Вказ. праця. - С.43.

34. Aftanazy R. Op.cit. - S.413.

35. Ibid.

36. Rychkov P., 2012. Zespól pałacowo-ogrodowy Lubomirskich w Równem w świetle małoznanego dzieła Jana Jacuba Bourguignona // Biuletyn Historji Sztuki: Kwartalnik wydawany przez Instytut Historii Sztuki Polskiej Akademii Nauk. - 2010, nr.3. - S.335-349; Ричков П.А. Діонісій Міклер та Ян Якуб Бургіньйон - дві постаті в історії садово-паркового мистецтва Волині // Парки Діонісія Міклера: Матеріали міжнародної науково-практичної конференції присвяченої 250-ї річниці з дня народження видатного ландшафтного дизайнера, а також формуванню та розвитку садово-паркового мистецтва на землях Східної Європи. - Збараж-Вишневець-Кременець, С. 165-174.

37. Aftanazy R. Op.cit. - S.116.

38. Bowe P. Op.cit. - P. 179.

39. Михайлишин О.Л. Вказ. праця. - С. 43.

40. Ibid.

41. Aftanazy R. Op.cit. - S.163.

42. Aftanazy R. Op.cit. - S.542.

43. Żelechowska K., Ciołek G. Op.cit.. - S.22.

44. Aftanazy R. Op.cit. - S.121.

45. Михайлишин О.Л. Вказ. праця. - С.130.

46. Żelechowska K., Ciołek G. Op.cit. - S.24.

47. Aftanazy R. Op.cit. - S.233.

48. Aftanazy R. Op.cit. - S.238.

49. Żelechowska K., Ciołek G. Op.cit. - S.32.

50. Żelechowska K., Ciołek G. Op.cit. - S.33.

51. Ibid.

52. Aftanazy R. Op.cit. - S.524.

53. Żelechowska K., Ciołek G. Op.cit. - S.39.

54. Radziwiłł M. F. Radziwiłł H. Ostatnia wojewodzina wileńska. - S.1., 1892. - S.237.

55. Przezdecki A. Op.cit. - S. 127. 